\title{
Human Resources Development of Public Service Providers in Labuhanbatu Selatan Regency
}

\author{
Wildan Aswan Tanjung ${ }^{1}$, Sampara Lukman ${ }^{2}$, Khasan Effendy $^{3}$, Aries Djaenuri ${ }^{4}$ \\ 1,2,3,4 Institut Pemerintahan Dalam Negeri (IPDN), Indonesia \\ Email:wildan.at@gmail.com
}

\begin{abstract}
This study discusses the development of human resources of public service providers in Labuhanbatu Selatan Regency. The research is expected to provide an understanding of the current picture of ASN conditions and what strategies are taken by the local government of Labuhanbatu Selatan Regency to improve ASN competence. The method used in this study is a qualitative analysis method by collecting data by interviewing and collecting literature related to this research. The results showed that the development of resource competencies an Investment of the One-Stop Integrated Services Office still needs to be improved, primarily managerial and socio-cultural competencies. This development can be done by making a roadmap so that development can be carried out continuously.
\end{abstract}

Keywords: Competence, State Civil Apparatus, Regional Personnel Agency, Local Government.

\section{A. INTRODUCTION}

Human Resources is the most crucial part of a government organization. Whatever the shape and purpose of government organizations are made with the aim of the interests of humanity itself. The importance of human resources in a government organization requires every organization to get qualified and productive employees to run the organization.

In the era of fierce global competition, human resources are considered as one of the essential factors, playing a necessary role in maintaining organizational sustainability, credibility and building public trust. The emphasis on human resources is valuable capital in an organization, which reflects the emphasis on intangible resources rather than actual resources. As stated by (Becker, 1964) that investment in human resources aims to benefit the organization both in the long run long or short. Through the skills and abilities possessed by employees will be motivated to continue learning to build a superior business environment. Human resources used significantly as the driving power source other and have a strategic position to contribute to making the performance of the company with a competitive advantage (Wright, 2005). Paulus \& Anantharaman (2003), emphasized that human resource development has a direct relationship with organizational profitability. Therefore, every organization is recommended to optimize the performance of employees in providing 
optimal contribution, among others, by way of a program of training and development. This also relates to organizational productivity and can increase the effectiveness and efficiency of work.

Likewise, organizations where employee performance is closely related to the provision of services to the public. Even though it is a non-profit organization, employees must have high-quality standards because this can affect the credibility of government agencies. One indicator held by employees is education. Factors other than the development of human resources has a relationship with employee performance such as career development, transfer, promotion of employment and compensation. Through this development, employees will work on the principles of transparency and professionalism as the main drivers, which will ultimately create good governance.

Labuhanbatu Selatan Regency as one of the regencies in North Sumatra Province is an area located in the border region between North Sumatra and Riau provinces. The strategic position and the potential of the wealth of natural resources owned is the main capital for this region in advancing the region and improving the welfare of the community. This can be realized if supported by the performance of Apparatus Resources that are good and professional in managing government in Labuhanbatu Selatan Regency. Based on the background mentioned above, this study was conducted to examine the factors associated with the development of human resources that affect the performance of the State Civil Service providers of public services in the Government of Labuhanbatu Selatan Regency.

\section{B. LITERATURE REVIEW}

Human Resources (HR) in public sector organizations is one of the keys to organizational success, without apparatus, the organization will not be able to run, and organizational goals will not be achieved. Therefore, to achieve organizational goals, the existence of apparatus resources must be developed by using considerations such as: (1) Strategic Planning Dimension, (2) Structural Dimensions, (3) Process Dimension, (4) Value and Cultural Dimensions, (5) Functional Performance Dimension, (6) Organizational Dimension, (7) Leadership and Managerial Dimensions, (8) LaborManagement Dimension, (9) Environmental Dimension, (10) Technological Dimension (Farazmand, 2007).

Fillippo in Hardjanto (2010), explains that the development of human resources or apparatus is the preparation of people or employees to get a higher burden of responsibility in the organization. Human resource development is closely related to the increase in intellectual abilities needed to carry out better work. Human resource development is grounded in the fact that every workforce, employee, or apparatus needs better knowledge, expertise and skills. Development should focus more on longterm needs, and the results can only be measured in the long term. The development of human resources or apparatus is expected to be able to achieve organizational goals 
through effective and efficient employee performance. Also, the development of human resources or apparatus aims to improve the effectiveness and productivity of work in implementing and achieving the targets set.

Based on an understanding of human resources, it can be concluded that the development of the apparatus is the process of enhancing the conceptual, technical and employee morale skills. Employee development can be done through formal education, non-formal education and informal education. Development of the apparatus must be planned and directed. Development efforts through education and training are an integral and inseparable part. This is because the development that refers to the problem of staff and personnel is a long-term educational process using a systematic and organized procedure. At the same time, training is a short-term educational process using a systematic procedure. Development of apparatus resources is learning activities held within a certain period in order to increase the possibility to improve performance (Sulistyani, 2004).

Furthermore, Notoadmojo in Harsono (2006), divides two aspects in the development of the quality of human resources, namely physical aspects and nonphysical aspects. In order to improve physical quality can be pursued through health and nutrition programs, while to improve non-physical quality, then efforts education and training is very much needed. On the other hand, Emmerij in Tadjudin (1993) formulates the development of human apparatus resources is an action: first, the creation of human resources. Second, its development. Third, arrange an incentive or wage structure following available employment opportunities. These three definitions contain efforts to improve quality human resources through formal education and training and the utilization of these resources.

In order to build quality human resources that can be used as intellectual capital for the organization, systematic, sustainable and comprehensive efforts are needed. These efforts are not only carried out through formal education participated by members of the organization but also supported by a conducive organizational climate. This is because intellectual capital must be built through scientific traditions, with strong political support from decision-makers (Steward, 1997).

Development of apparatus resources needs to be focused on developing: (1) skills and expertise; (2) insight and knowledge; (3) talent and potential; (4) personality and work motives; and (5) morale and work ethic. In order to realize the development of apparatus resources in the targeted area, it is necessary to pay attention to four basic phases that will be passed, namely: (1) the design phase includes the involvement of parties who can produce input for apparatus resource development strategies, both from within and from outside government institutions; (2) the project implementation phase, in which this phase selects the implementing contractor or specific administrative units to start and implement a program; (3) the ability acquisition phase, namely through the activities and training that occur as well as the informal experience 
gained will form new skills; (4) the phase of achieving performance, where individual abilities will be manifested in the shift of tasks and the results of the final evaluation (Grindle, 1997).

In order to develop the capacity of apparatus and institutional resources in the region, the government needs to establish cooperative relations and develop networks to conduct learning processes with other districts or cities both inside and outside the country, educational institutions such as universities and NGOs that are in line with the needs of resource development apparatus power. Capacity building also needs support in the form of a conducive environment and the right approach. The approaches that can be used include: (1) the existence of a strategic intervention; (2) institution building; (3) direct action and learning through the action; and (4) improvement of sustainability (Suprapto, 2003).

Based on the above explanation Sikula in Hardjanto (2010), explains eight types of human resource development goals, namely:

a. Productivity (achieving productivity of personnel and organization)

b. Quality (improve product quality)

c. Human resources planning (carrying out human resource planning)

d. Moral (increase the morale and responsibility of personnel)

e. Indirect compensation (increase compensation indirectly)

f. Health and safety (maintaining mental and physical health)

g. Obsolescence prevention (preventing the decline in the ability of personnel)

h. Personal growth (increasing the ability of individual personnel

Then Sedarmayanti (2009), explains that the strategic purpose of developing or fostering civil servants is to create a professional state apparatus, neutral from political activities and influences, high moral, global-minded, supporting national unity and unity, and having a material health level and spiritual.

Based on the description in the above can be concluded that the development of resources human resources organization in an organization, especially the public sector, is one essential thing. This is because, with quality and superior human resources, the organization can follow developments and respond to environmental changes that occur and be able to adjust.

\section{METHOD}

In this study, researchers used a qualitative research approach. Qualitative research, according to Lincoln and Guba (1985), is called a naturalistic method. Through a qualitative approach, researchers find and describe a phenomenon that has a unique character associated with the performance of local governments in the delivery of public services in Labuhanbatu Selatan Regency. The reason for using qualitative research methods in this study is because it is considered appropriate, and there is a match between the characteristics of qualitative research with the phenomenon under 
study. In this study, researchers used descriptive research, which is only limited to describing a phenomenon or object as it is, without any intention of drawing conclusions that are generally accepted. Besides, the reason for using this type of descriptive qualitative research, because this research aims to capture various information phenomena, especially those related to the focus of the research, besides, this approach can present a holistic or comprehensive form in analyzing a social phenomenon that exists in the Autonomous Region of Labuhanbatu Selatan Regency.

\section{RESULTS AND DISCUSSION}

The main task of the South Labuhanbatu Regency Government is to provide the best service to the community. However, the condition of the public service is recognized as not being able to satisfy the community, especially licensing and population services entirely. This is due to the inadequate limitations of government facilities and infrastructures such as office facilities and professional government apparatus that are still very limited. To improve public services to the community, the South Labuhanbatu Regency Government continues to make improvements in all sectors, especially in improving the quality and quantity of the government apparatus. Civil Servants in the District Government of South Pelabuhanbatu continue to experience changes in line with the appointment of new employees. Until December 2015, the number of employees of the South Labuhanbatu Regency Government was 3,046 people with composition in terms of rank and class including group I as many as 16 people or $0.53 \%$, group II as many as 454 people or $14.90 \%$, group III as many as 1,826 people or $59.95 \%$ and group IV as many as 750 people or $24.62 \%$.

Overall, the Labusel District Civil Service Agency considers that it still lacks incompetence when compared to its quantity. This is allegedly due to the dynamics of government regulations that are not supported by the ability of local governments to follow them. For example, in 2000, the elimination of the Office of Social Affairs and Transmigration, which had an impact on the transfer of employees to regions with various backgrounds that accessed the recruitment of employees, was not based on organizational and regional needs. The next instruction is the appointment of non-civil power/honorarium, Implication on human resources databases that are not based on the needs that can be met agriculture graduate work at the hospital, and so that eventually followed up with the arrangement after the employee concerned. Conditions dilemma is often experienced Board of Regional Employment in the structuring of personnel resources in the area, such as scientific background is not linearly followed by equalization competence in order to impartial into the Civil Service.

Implementation of Individual Work Standards (SKP) and associated with the provision of performance allowances is very effective in helping to manage performance in the Labusel Regency Government. By the implementation of the system, what is done today is inputted in a periodic performance reporting system that 
will be evaluated and assessed by the leadership periodically for approval or disapproval. Performance reporting must be followed up with the management's approval. Although in its implementation, it is not yet $100 \%$ appropriate. For the time being, a system that is using evidence in this periodic performance report is being prepared.

The problem in the spotlight is the commitment and sincerity of office holders in carrying out their mandate. This is proven when competency development activities are attended by the person concerned, not vice versa, representing his subordinates. Related to the problem of lack of functional staff, the Labusel Regency Government still needs functional personnel in the field of public services (health, education, investment ), especially specialists. For technical personnel in the civil field, the Government of Labusel Regency still needs a lot, especially planning and spatial engineering or public relations techniques. The Regional Personnel Agency has also developed a competency development map for the structural ranks from echelon 2 to echelon 4. However, it still needs to be refined, especially because soft competency can change so that it will be renewed every two years.

Constraints in the development of competencies such are Frame which not effective and does not suit the needs of organizations and individuals concerned as personnel transfers. The next obstacle is the need for criteria to reduce the number of mutations out of the region before the service period ends, for example when the service period is 15 years and is still running for five years but has moved outside the region which results in depriving the local people of the opportunity to develop their region without undermining the role outsiders who committed devote themselves in areas such. The weaknesses in the implementation of competency development include not yet optimal implementation of the employee development roadmap, which is due to budget constraints and the limitations of the employees themselves.

ASN management is very important especially to avoid local governments that are not in line with the direction of national policy, which is the task of the high leadership to oversee the policies of the regional head, the policies of the provincial government and the central government as the implementation of an open auction (open biding) is actually to avoid and minimize the like and dislike factors and indeed to get a quality figure and qualified. Not related to seniority issues only related to competence, ability, soul maturity and so on.

Meaning of competence is related to officials' insights related to the extent of understanding the area of responsibility which is then described in strategic programs going forward. Competency requirements related to regional content are the need for a competency roadmap and a competency roadmap that is needed in managing regional potential and public services.

Regional Work Units that manage Regional content in Labusel Regency are the Agriculture, Trade and Cooperatives Office and the Public Transportation Agency. This 
is because the largest contributor to the GDP of Labusel Regency is agriculture, processing and infrastructure. Besides, no less important is the office which organizes public services, namely the Investment Office and PTSP. More details are described in the subsections below.

a. Managerial Competence

Gaps in managerial competence also still exist, as in general in other areas, which require much full support from the leadership. For example, often events such as pre-LAKIP and so on are still represented and not attended by the Regent, Deputy Regent or regional secretary. For senior management (echelon 2), there should be more in terms of the ability to foster and be responsible for solving the problems of the Dinas units they lead and not to give up their hands. For example, some employees are difficult to regulate. Those who are appointed are $\mathrm{BKD}$, not the leaders themselves so that the ability to foster and direct subordinates must also be possessed by the head of the service unit. Not only that, as an element of high leadership, but many of the managerial competencies that must be owned and felt are also still lacking and need to be improved, considering JPT's role as head of the organization is compared to blood in human organs, which plays a vital role in the direction the organization is run. Among them is the courage to take risks, minimize sectoral egos, understand authority and responsibility, decision-making abilities, and the role of coaching, directing subordinates and the role of the teacher for his subordinates.

b. Socio Cultural Competencies

Related plurality Labusel society, so far it does not exist problems related to socio-cultural. Potential and regional development planning become the basis in the preparation of the competency roadmap, and the competency needs a roadmap, with the evaluation expected to be able to read the needs of the future as what is the basis for formulating future policies. Moreover, the geographical condition of Labusel Regency which is in the area of oil palm and rubber plantations where in the future Labusel Regency has the potential to be the largest producer of palm and rubber in North Sumatra.

Labusel Regency Development Planning is outlined in the 2016-2021 RPJMD. As a strategic step in the essential briefing period from 2016-2021 is the preparation of Human Resources (HR) with infrastructure support where HR development is a development priority as the basic framework of Labusel Regency in future development. The RPJMD as a five- year medium-term plan (2016-2021) is the first period of the RPJPD of Labusel Regency, or in the basic briefing period from 2016-2021, it is the second stage after the initiation period. At this stage, the preparation of Human Resources (HR) and infrastructure is still the focus of development as a prerequisite for the economic development of the city which is the focus of the next stage of development (2016-2020). 
In entering the fourth year of the Labusel Regency RPJMD, the 2019 development goals and objectives refer to the 2011-2016 Labusel Regency Government's Vision: "Together to Build a Self-Based, Competitive and Prosperous Soil".

Within the scope of Labusel Regency development planning, the vision of development in the 2016-2021 RPJMD is a description of the third period of development of the Labusel Regency RPJPD 2005 - 2025. With this development vision, it is expected to direct the development process and stages of realizing the hopes, desires and mandates of the people of Labusel Regency. As an integral part of the national development goals as mandated in the Preamble to the 1945 Constitution, the establishment of the Labusel Regency development policy still refers to and supports the achievement of national development goals and is vertically aligned with the National RPJMD and North Sumatra Province RPJMD. In order to realize the vision of development, demands and commitment from all parties are demanded so that the management and utilization of the potential resources of Labusel Regency which is the basic capital for the implementation of regional development can guarantee an increase in community welfare as a "main goal" of the established development vision.

Efforts to realize this vision, it is deemed necessary to develop a mission as a translation of the vision that has been set. With the mission statement, it is hoped that all Labusel Regency Government officials and interested parties can know and recognize the existence and role of the Labusel Regency Government in the administration of government. The mission of the Labusel Regency government in 2016-2021, namely:

a. Realizing and improving the quality, function and role of an independent and dignified economy, social, culture and religion through the use and management of local resources and environmental insight;

b. Improving the quality of infrastructure that supports industrial and regional development and community welfare;

c. Building quality human resources through equality and justice in the nation and state, religiously cultured and competitive;

d. Building sustainable bureaucratic reforms to improve good, clean and authoritative governance.

The strategy undertaken in developing the competence of the State Civil Apparatus and Officials within the Labusel Regency Government is to conduct training in addition to spiritual treats both for Muslims ( Muslims) and non-Muslims (Christians and so on) every one month for the leadership ranks. The focus is on enlightenment how to become a leader, understanding the role and duty as a leader who emphasizes the direction of conscience / spiritual.

The strategy for overcoming competency deficiencies at the high leadership level is to develop a roadmap in the next few years. We have then given facilitation, 
coaching, mentoring the nature sustainably. Not only providing education and training then finished will, however, have to be monitored and assisted.

Then learn from the experience of managing organizations on an international scale in which the CSR (Corporate Social Responsibility) program provides assistance and assistance and is then given ongoing training. The following year was given training that supports the training beforehand so that there is eyes chain competence that developed, and do not walk sporadically/separated individually.

The importance of the competency roadmap and the training needs a roadmap to be urgent to be compiled in each agency so that it can be asked to BKD in fulfilling the competencies required in his position. It is hoped that this will be carried out for the high ranks as well as the authority, main tasks and functions, RPJMD, Renstra, Renja which are the reference for work must all be understood by leaders and the ranks below. With this, it can be seen the potential, strengths, weaknesses and strengths to formulate a strategy of what that can do for the development potential of the region.

The right strategy in developing this competency is to build a shared commitment that is not only at the beginning but is always continually updated. That commitment is built from understanding the vision and mission of the organization and then followed by the fulfilment of the required competencies.

\section{E. CONCLUSION}

The competency of the PTSP Investment Service personnel apparatus still needs to be improved, especially managerial and socio-cultural competencies. Increased competence of personnel needed in lacquers by developing a roadmap for the next few years. Then given facilitation, guidance, sustainable assistance. Not only providing education and training then finished will however have to be monitored and assisted. Development of joint commitments that are not only in the beginning but are continuously renewed in the development of competencies.

\section{REFERENCES}

1. Alderfer, H. F. (1965). Local Government in Developing Countries. New York: Mc. Graw-Hill.

2. Analoui, F. (2009). Reform in international institutions: the case of the United Nations. Journal of Management Development, 28(6), 495-503.

3. Baker, M., \& Neailley, K. (2003). From Individual Learning to Project Team Learning and Innovation: A Structured Approach. Journal of Workplace Learning, 11(2).

4. Dobni, C. Brooke, 2008. Measuring Innovation Culture in Organizations: The Development of a Generalized Innovation Culture Construct Using Exploratory Factor Analysis. European Journal of Innovation Management, 11(4), 539-559. 
5. Dwiyanto, Agus. (2002) Reformasi Birokrasi Publik di Indonesia. Yogyakarta: PSKK UGM.

6. Fenwick, J., \& Bailey, M. (1999). Local Government Reorganisation in the UK: Decentralisation or Corporatism?. International Journal of Public Sector Management, 12(3), 249-261.

7. Glaser, B. G. (1992). Basic of Grounded Theory Analysis: Emergence vs Forcing. Mill Valley, CA: Sociology Press.

8. Government Regulation Number 101 of 2000 concerning Positioning Education and Training for Civil Servants.

9. Government Regulation No. 38/2007 concerning the Sharing of Government Affairs between the Government, Provincial Governments and Regency/Municipal Governments.

10. Government Regulation Number 7 of 2008 concerning Deconcentration and CoAdministration

11. Kamensky, J. (1996). The Role of Reinventing Government in Federal Management Reform. Public Administration Review, 56(3).

12. Kulshreshtha, P. (2008). Public Sector Governance Reform: The World Bank's Framework. International Journal of Public Sector Management, 21(5), 556 - 567.

13. Law of the Republic of Indonesia Number 32 of 2004 concerning Regional Government.

14. Law Number 22 of 1999 concerning regional government.

15. Law Number 25 of 1999 concerning Public Services.

16. Law Number 18 of 2002 concerning the National System of Research in the Development and Application of Science.

17. Moeleong, L. J. (2006). Metodologi Penelitian Kualitatif. Bandung: Remaja Rosdakarya.

18. Musgrave, R. A. \& Musgrave, P. B. (1991). Keuangan Negara Dalam Teori dan Praktek. Jakarta: Erlangga.

19. Regulation of the Minister of Administrative Reform and Bureaucratic Reform of the Republic of Indonesia Number 38 of 2012 concerning Guidelines for Performance Evaluation of Public Service Units.

20. Rondeaux, G. (2006). Modernizing Public Administration: The Impact on Organisational Identities. International Journal of Public Sector Management, 19(6), 569584.

21. Rouban, L. (2008). Reform without Doctrine: Public Management in France. International Journal of Public Sector Management, 21(2), 133-149.

22. Siddiquee, N. A. (2006). Public Management Reform in Malaysia: Recent Initiatives and Experiences. International Journal of Public Sector Management, 19(4), 339-358.

23. Skalen, P. (2004). New Public Management Reform and the Construction of Organizational Identities. International Journal of Public Sector Management, 17(3), 251-263. 
24. Stauss, A., \& Corbin, J. (1998). Basic of Qualitative Research: Grounded Theory Procedures and Techniques. Newbury Park, CA: Sage Publications.

25. Straussman, J. D., \& Mengzhong, Z. (2001). Chinese Administrative Reforms in International Perspective. International Journal of Public Sector Management, 14(5), 411-422.

26. Tuner, M., \& Hulme, D. (1997). Governance, Administration and Development, Making the State Work. London: Macmilan Press Ltd.

27. Vigoda-Gadot, E. (2004). Collaborative public administration: Some lessons from the Israeli experience. Managerial Auditing Journal, 19(6), 700-711.

28. Zauhar, S. (1996). Reformasi Administrasi: Konsep, Dimensi, dan Strategi. Jakarta: Bumi Aksara. 